\title{
The Effect of Board of Directors Characteristics on Firm's Financial Performance: An Empirical Study on the Most Active Firms in the Egyptian Stock Exchange
}

\author{
Ashraf Mohamed Abdel Atty, Mohamed Moustafasoliman, Amr E. Youssef \\ The Arab Academy for Science and Technology \& Maritime Transport, Alexandria, Egypt \\ Email: ashraf.atti@gmail.com
}

How to cite this paper: Atty, A.M.A., Moustafasoliman, M. and Youssef, A.E. (2018) The Effect of Board of Directors Characteristics on Firm's Financial Performance: An Empirical Study on the Most Active Firms in the Egyptian Stock Exchange. Open Access Library Journal, 5: e4993.

https://doi.org/10.4236/oalib.1104993

Received: October 18, 2018

Accepted: November 27, 2018

Published: November 30, 2018

Copyright $\odot 2018$ by authors and Open Access Library Inc.

This work is licensed under the Creative Commons Attribution International License (CC BY 4.0).

http://creativecommons.org/licenses/by/4.0/

\begin{abstract}
This paper seeks examining the effect of Board of Directors Characteristics on firm's financial performance in Egypt, using a sample of 50 more active Egyptian companies listed on the Egyptian Stock Exchange of the non-financial sector covering the period of three financial years from 2012 to 2017. Board of Directors Structure is represented by CEO Duality, Board Size, Board Meetings, Independence board members and Gender Diversity. Return on Assets (ROA), Return on Equity (ROE) and Tobin's Q is used as a proxy for Firm financial Performance. In this research, correlation and regression analysis are used to examine the relationship between Corporate Governance and firm's financial performance.
\end{abstract}

\section{Subject Areas \\ Business Analysis}

\section{Keywords}

Corporate Governance, Board of Directors, Firm Financial

Performance, Egypt

\section{Introduction}

Today, corporate governance has become a priority for the economic growth of any nation [1]. It is safe to assume that fifteen years ago the normal citizen would not have comprehended the significance of corporate governance. In fact, it is very probable that the normal citizen would not have even recognized that 
corporate governance existed. Throughout the years, however, that lack of awareness has radically changed [2].

The collapse of several companies worldwide has had a particularly significant role in increasing the significance of corporate governance both in the USA and in other parts of the world. Since the 1930s, organizational scholars have developed theoretical frameworks related to corporate governance along such dimensions as board characteristics, transaction costs, institutional one-to-one correspondence, and behavior of agents, occupational communities, resource dependence, and stakeholder management [3].

Good corporate governance has become significant in protecting investors and in strengthening and stabilizing capital markets. Sound corporate governance improves firm performance, hence attracting investment [4]. Good corporate governance also enables management to recognize corporate objectives, meet legal requirements, protect shareholder rights, and demonstrate to the public how the business is running and how is it conducting its operations [5].

The focus of this study is to investigate the relationship between Board of Directors Characteristics and firm financial performance in the Egyptian firms.

\section{Literature Review}

The board of directors, an important mechanism in a company, holds the responsibility for leading and directing a firm, as well as protecting the interests of the company's shareholders [6]. More specifically, the board of directors performs several functions, such as deciding the appropriateness of the company's strategies [7]; monitoring and controlling managers [8]; appointing, supervising and remunerating senior managers [9]; linking the corporation to the external environment; and providing information to managers.

These functions make the board of directors one of the important internal corporate governance control mechanisms in an entity [9]. Conversely, boards of directors have been criticized for corporate failures and the decline of shareholder value [10].

\subsection{CEO Duality and Firm Financial Performance}

Agency theorists advocate separation of the chief executive officer (CEO) and board chair positions as necessary to avoid managerial entrenchment and to curb the CEO's power [11]. When the CEO is also the chair, it becomes more difficult to replace the CEO for poor performance [12]. According to agency theory, duality "signals the absence of separation of decision management and decision control" [13]. Unitary leadership can lead to opportunistic behaviors at the expense of shareholders [14].

One aspect of corporate governance, which has given rise to concern, is the dominant personality phenomenon that includes role duality, where the chief executive officer (CEO) is also the chairman of the board [15]. A CEO is a full-time post and he/she is responsible for the operation of the company and 
strategic implementation, whereas the chairman of the company is responsible to monitor and evaluate the executive directors including the CEO [16]. In addition, he/she is responsible to chair the meeting and monitor the appointment process, termination, evaluation and provide compensation for senior management.

Therefore, the separation of the post between CEO and chairman of the company is important for effective monitoring. However, the advantage of the same person serves both posts is that he/she will have a better understanding and knowledge on the firm operation and environment [17].

Consequently, this research proposes the following main hypothesis:

$H_{1}$ : There is a significant positive relationship between CEO Duality and firm's financial performance.

This hypothesis will be divided into the following sub hypotheses:

$H_{1.1}$ : There is a significant positive relationship between CEO Duality and firm's financial performance measured by ROA.

$H_{1.2}$ : There is a significant positive relationship between CEO Duality and firm's financial performance measured by ROE.

$H_{1.2}$ : There is a significant positive relationship between CEO Duality and firm's financial performance measured by Tobin's Q.

\subsection{Board Size and Firm Financial Performance}

Board size has been shown to be a significant part of the ability of boards to effectively monitor management and to work efficiently together to oversee the running of the business [18]. Board size is an indicator of both its monitoring and advisory roles, both of which may contribute to its insight into management behavior (e.g., [19] [20]). Larger boards are likely to provide more expertise and diversity and to increase the board's monitoring capacity [21]. Additionally, larger boards are more likely to include more independent directors with valuable experience and, hence, they are able to delegate more responsibilities to board committees than smaller boards; this also can prevent or limit managerial opportunistic behavior [22].

The agency theory argues that the larger a board is, the more it can reduce conflicts between shareholders and management because of the board's increased caution and watchfulness to monitor the firm's management's actions [23]. In addition, [23] added that large boards provide more access and links to a firm's resources. From data obtained from Australian firms, [23] deduced that the relationship between a board's size and Tobin's Q is a positive one. [27] state that, in relation to the agency theory, larger boards are associated with better performance and to the corporation's operations as a whole.

Theoretically, [27] states that according to the agency theory, larger boards are associated will better performance and will most likely be beneficial to the corporation as a whole. An empirical study by [25] examines the relation between board size and firm performance, concluding that the smaller the board size, the 
better the performance, and proposing an optimal board size of ten or fewer. Theoretically, a [24] state that according to the agency theory, larger boards is associated will better performance and will most likely be beneficial to the corporation as a whole. A meta-analysis for US firms found a positive relationship between board size and firm performance [26]. Consequently, this research proposes the following main hypothesis:

$\mathrm{H}_{2}$ : There is a significant positive relationship between Board Size and firm's financial performance.

This hypothesis will be divided into the following sub hypotheses:

$H_{2.1}:$ There is a significant positive relationship between Board Size and firm's financial performance measured by ROA.

$H_{2.2}$ : There is a significant positive relationship between Board Size and firm's financial performance measured by $R O E$.

$H_{2.3}:$ There is a significant positive relationship between Board Size and firm's financial performance measured by Tobin's $Q$.

\subsection{Board Meetings and Firm Financial Performance}

Board of directors carry out critical roles, and thus deemed to be an important Corporate Governance mechanism ([27] [28]). Specifically, it has been suggested that board of directors' advice, supervise and seek accountability from management to ensure that managers pursue the interests of shareholders [29].

According to the agency perspective, the more the board exhibits greater conscientiousness in discharging its responsibilities, the more control it will gain and the more the level of oversight will be improved. [27] reported that running out of time in accomplishing board duties could be a considerable obstacle to the board's effectiveness. In this sense, meeting frequently enables the board to perform its duties persistently while considering shareholders' interests [30].

A previous study using a sample of 307 US listed firms over the period of 1990-1994, [25] reports a statistically significant and negative association between the frequency of board meetings and corporate performance, as measured by Tobin's Q. Also, and of close relevance, [31] report a positive relationship between the frequency of board meetings and corporate performance for a sample of 157 Zimbabwean listed firms over the period 2001-2003. Their results support the proposition that companies whose board meet more frequently perform better. [24] finds that the frequency of board meetings has no association with financial performance in a study conducted on a small sample of 24 Tunisian listed firms from 2000 to 2005 .

Consequently, this research proposes the following main hypothesis:

$H_{3}$ : There is a significant positive relationship between board meetings and firm's financial performance.

This hypothesis will be divided into the following sub hypotheses:

$H_{3.1}$ : There is a significant positive relationship between Board Meetings and firm's financial performance measured by ROA. 
$H_{3.2}:$ There is a significant positive relationship between Board Meetings and firm's financial performance measured by ROE.

$H_{3.3}:$ There is a significant positive relationship between Board Meetings and firm's financial performance measured by Tobin's $Q$.

\subsection{Board Members Independence and Firm Financial Performance}

A non-executive board member refers to the distinction between inside and outside directors, and is traditionally measured as the percentage of non-executive directors on the board. It may be noted, however, that alternative definitions of outside directors have been utilized [32]. Agency theory contends that a primary function of the Board is to monitor, oversee and, if need be, discipline management [33]. But, inside directors are less likely to challenge and question the CEO since insiders are members of the senior management team who directly report to the CEO.

Outside directors, on the other hand, are not members of senior management; as such, outsiders are appointed to the Board to oversee and monitor management. The presumption is that because of their independence from management, they can provide greater oversight and shareholder protection. An independent board of Directors may provide the diverse inputs into strategic decision-making to promote a broader stakeholder orientation. Therefore, they should be better able to execute this oversight function since their interests are more closely aligned with the interests of the other investors [34].

The independent board is more likely to be vigilant for agency problems as it includes a substantial number of non-executive directors (NEDs) who are dedicated to monitoring management's performance and behavior (e.g. [35]). [36] state that independent non-executive directors have the potential to detect earnings management. This leads to reduced level of earnings management in their presence on board. Consequently, this research proposes the following main hypothesis:

$H_{4}$ : There is a significant positive relationship between Independence board members and firm's financial performance.

This hypothesis will be divided into the following sub hypotheses:

$H_{4.1}:$ There is a significant positive relationship between Independence board members and firm's financial performance measured by ROA.

$H_{4.2}$ : There is a significant positive relationship between Independence board members and firm's financial performance measured by ROE.

$H_{4.3}$ : There is a significant positive relationship between Independence board members and firm's financial performance measured by Tobin's $Q$.

\subsection{Gender Diversity and Firm Financial Performance}

Boards are traditionally composed of only male members. The presence of women on the board leads to gender diversity. It is generally accepted that fe- 
male board members are more independent because they are not part of the "old boys" network [37]. Financial scandals and the high failure rate of companies over the past decade, as well as the 2008 financial crisis, have increased concerns about improving board effectiveness [38]. In this regard, board diversity has been considered to be a mechanism to increase such effectiveness. Diversity can be categorized into two groups: demographic (i.e. gender, age, ethnicity and race) and cognitive (i.e. knowledge, education, values and perception) [39].

[40] investigate the effect of Norwegian law requiring all public-limited firms to have at least 40 percent representation of women on their boards on firm value. They show that the firm value, as measured by Tobin's $Q$, declines as a result of this mandated change. Using German data [41] show that for women on board to add value to the firm, there is a threshold of 30 percent, and only above this level performance of a diverse board exceeds the completely male board. In addition, using new additions of female directors/managers as a measure of gender diversity for Turkish firms, [42] show that gender diversity has different effects on firm performance over the different points of the conditional distribution. Hence, the effect might be negative, positive or zero depending on the quantile analyzed.

[43] investigate the role of gender diversity on firm performance for the largest listed firms in Turkey and the result show that women add a new perspective to the firm strategy to improve firm performance. Also, the results imply that gender diversity may have a larger role if firms have more women directors rather than women CEOs/GMs. Consequently, this research proposes the following main hypothesis:

$H_{5}$ : There is a significant positive relationship between Gender Diversity and firm's financial performance.

This hypothesis will be divided into the following sub hypotheses.

$H_{5.1}$ : There is a significant positive relationship between Gender Diversity and firm's financial performance measured by ROA.

$H_{5.2}:$ There is a significant positive relationship between Gender Diversity and firm's financial performance measured by ROE.

$H_{5.3}:$ There is a significant positive relationship between Gender Diversity and firm's financial performance measured by Tobin's $Q$.

\section{Research Methodology}

\subsection{Data Collection and Sample Selection}

The sample consists of 50 most active companies on Egyptian stock exchange, which are 50 firms belong to 12 sectors, which are Basic Resources, Chemicals, Construction and Materials, Food and Beverage, Healthcare and Pharmaceuticals, industrial Goods and Services and Automobiles, Real Estate etc. In this study the researcher excludes the banking and insurance sectors because the characteristics of these firms are different from the firms in other industrial 
sectors in terms of specialized in nature and were subject to different regulations, tax and accounting rules [44]. The final sample consists of 37 firms. This paper uses secondary data only which is collected from the annual disclosure book issued by EGX. This study employed annual data from 2012 to 2017.

\subsection{Variables and Measurement}

The variables used in this study can be categorized into two main types which are; the dependent and independent variables.

\subsubsection{Dependent Variable}

The dependent variable for this study is the financial performance of firms in the Egyptian market. The performance will be measured by the Return on Assets (ROA), Return on Equity (ROE) and Tobin's Q ([55] [58]).

\subsubsection{Dependent Variable}

The independent variables employed in this study are factors identified in prior research as influences performance, either positively or negatively. There are five independent variables that will be measured. These are CEO Duality, Board Size, Board Meetings, Independence board members and Gender Diversity.

This research tried to look at the possibility of the relationship between dependent variable and independent variables. The relationship between dependent variable and independent variables is explained in Figure 1.

\subsubsection{Control Variables}

The control variables were selected in accordance to similar studies made on this

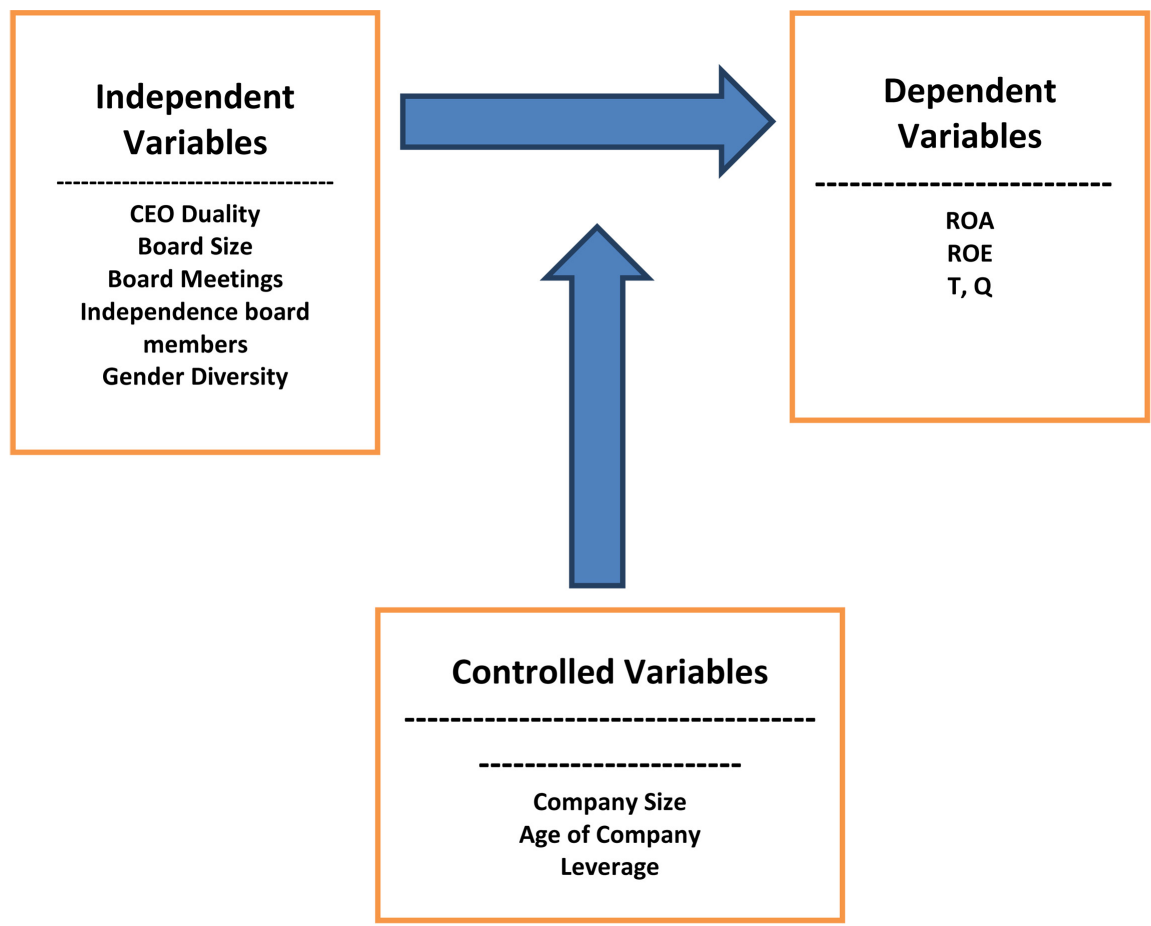

Figure 1. Relationship diagram between independent variables and dependent variable. 
topic ([52] [55]). The selected variables are Company Size, Age of Company and financial leverage. These variables are selected because they have been shown to have simultaneous effect on both Board of Directors and performance [56]. Table 1 presents a summary for all the variables including the dependent, independent and control variables of the study.

Table 1 presents a summary for all the variables including the dependent, independent and control variables of the study.

\subsection{Research Model}

To test the hypothesis common effect model in panel data analysis has been used.

$$
\begin{aligned}
P_{i, t}= & \beta_{0}+\beta_{1} \mathrm{CEOD}+\beta_{2} \mathrm{BSIZE}+\beta_{3} \mathrm{BMEET}+\beta_{4} \mathrm{BINDEP} \\
& +\beta_{5} \mathrm{Gendiv}+\beta_{6} \mathrm{~F} \mathrm{size}+\beta_{7} \mathrm{~F} \mathrm{Age}+\beta 8 \mathrm{~F} \mathrm{Lev}+\mathrm{e}
\end{aligned}
$$

where $P_{i, t}$ is the financial performance of firm $i$ in period $t$ represented by ROA, ROE and and T, Q; $\beta_{0}=$ Regression constant, $\beta_{1}=$ Regression coefficient for CEO Duality; $\beta_{1}$ CEOD, $\beta_{2}=$ Regression coefficient for Board Size ; $\beta_{2}$ BSIZE,

Table 1. Summary of dependent, independent and control variables.

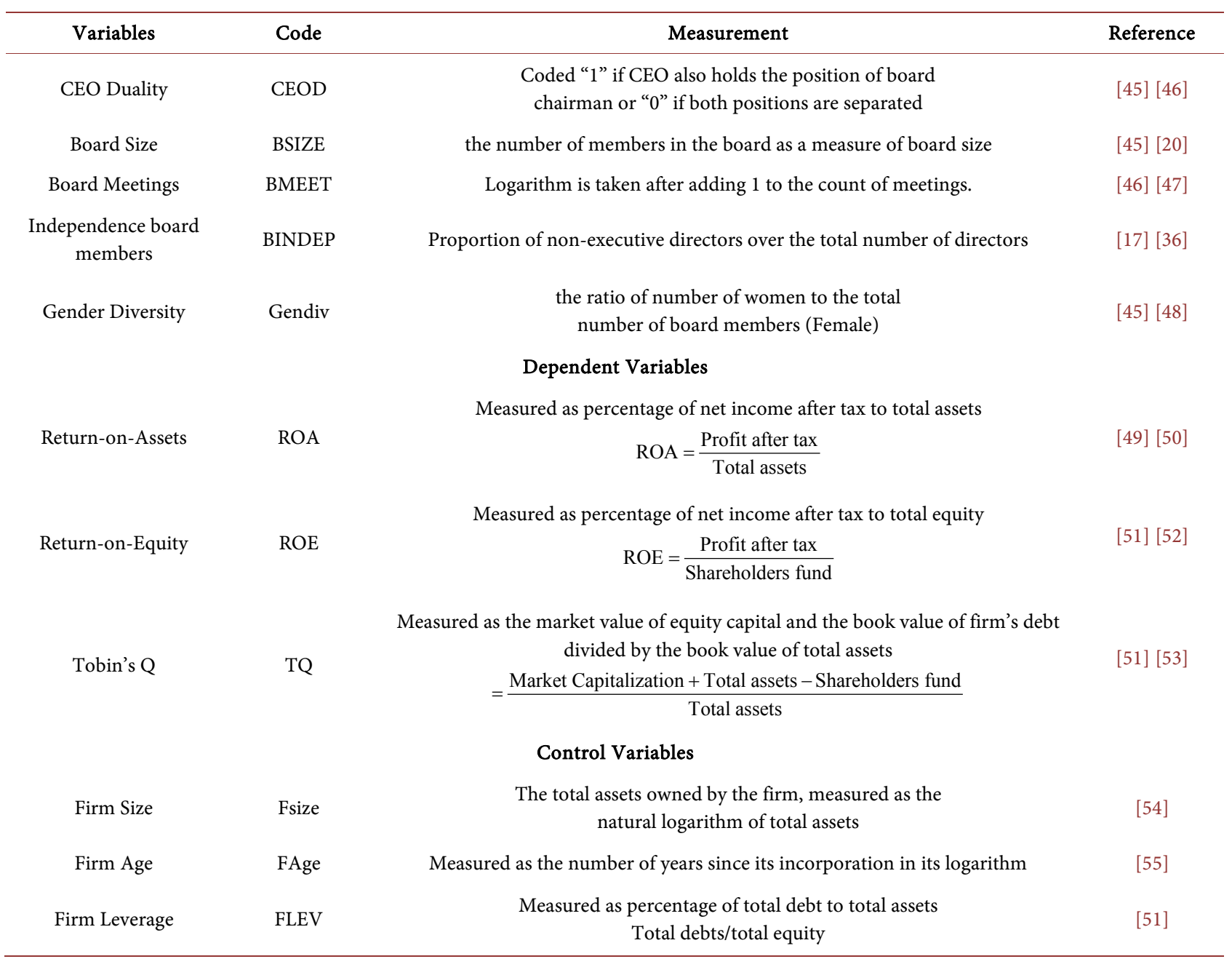


$\beta_{3}=$ Regression coefficient for Board Meetings; $\beta_{3}$ BMEET, $\beta_{4}=$ Regression coefficient for Board of Directors independence; $\beta_{4}$ BINDEP, $\beta_{5}=$ Regression coefficient for Gender Diversity; $\beta_{5}$ Gendiv, $\beta_{6}=$ Regression coefficient for Firm Size; $\beta_{6} \mathrm{~F}$ size, $\beta_{7}=$ Regression coefficient for Firm Age; $\beta_{7} \mathrm{~F}$ Age, $\beta 8=$ Regression coefficient for Firm Leverage; $\beta_{8}$ F Lev is the composite error terms. 4. Findings and Analysis

\subsection{Descriptive Statistics}

This section of the study is devoted to presenting the results of the analysis performed on the data collected to test the propositions made in the study and answer the research questions. Table 2 provides the mean, median and standard deviation of the variables in the study.

The data shows that nearly (68\%) of the firms have their chairman who also acts as EO (duality). The Results show that the mean of Board size is (7.7) and the mean of BOD Meetings is (8) also the average ratio of independent directors is $(58 \%)$. While the ratio of Gender Diversity is $(57 \%)$. The mean of return on asset ROA. 0735While the mean of return on equity ROE also the mean of $\mathrm{T}$, Q .9680.

\subsection{Descriptive Statistics}

Table 3 shows the regression model for the effect of Independent Variables; (CEO Duality, Board Size, Board meetings, Independence Board, Gender diversity,) on ROA. It was found that there is an insignificant effect of CEO Duality,

Board Size, Board meetings, Independence Board and Gender diversity, on

Table 2. Descriptive statistics.

\begin{tabular}{|c|c|c|c|c|c|c|}
\hline & Range & Minimum & Maximum & Mean & Std. Deviation & Variance \\
\hline $\begin{array}{c}\text { CEO } \\
\text { Duality }\end{array}$ & 1.00 & 0.00 & 1.00 & 0.6826 & 0.46685 & 0.218 \\
\hline Board Size & 14.50 & 0.50 & 15.00 & 7.6886 & 2.66768 & 7.117 \\
\hline $\begin{array}{c}\text { BOD } \\
\text { Meetings }\end{array}$ & 28.13 & -5.13 & 23.00 & 8.0421 & 6.01021 & 36.123 \\
\hline IND & 0.93 & 0.00 & 0.93 & 0.5811 & 0.27589 & 0.076 \\
\hline $\begin{array}{l}\text { Gender } \\
\text { Diversity }\end{array}$ & 0.50 & 0.00 & 0.50 & 0.0569 & 0.09759 & 0.010 \\
\hline $\begin{array}{c}\text { Company } \\
\text { Size }\end{array}$ & $40,470,988,380.10$ & 2553.90 & $40,470,990,934.00$ & $3,619,763,939.2872$ & $5,277,788,189.96422$ & $27,855,048,178,125,808,000.000$ \\
\hline $\begin{array}{c}\text { Age of } \\
\text { Company }\end{array}$ & 77.00 & 0.00 & 77.00 & 26.9200 & 18.68701 & 349.204 \\
\hline Leverage & 27.36 & 0.00 & 27.36 & 0.5298 & 1.74069 & 3.030 \\
\hline ROA & 3.73 & -0.39 & 3.33 & 0.0735 & 0.23964 & 0.057 \\
\hline ROE & 9.33 & -5.55 & 3.78 & 0.1293 & 0.54998 & 0.302 \\
\hline Q Ratio & 20.03 & -5.13 & 14.90 & 0.9680 & 2.89323 & 8.371 \\
\hline
\end{tabular}


Table 3. Regression model of board characteristics on ROA.

\begin{tabular}{|c|c|c|c|c|}
\hline \multicolumn{5}{|c|}{ Dependent Variable: ROA } \\
\hline \multicolumn{5}{|c|}{ Method: Panel Least Squares } \\
\hline \multicolumn{5}{|c|}{ Date: 06/10/18 Time: 13:07 } \\
\hline \multicolumn{5}{|c|}{ Sample (adjusted): 20142017} \\
\hline \multicolumn{5}{|c|}{ Periods included: 4} \\
\hline \multicolumn{5}{|c|}{ Cross-sections included: 22} \\
\hline \multicolumn{5}{|c|}{ Total panel (unbalanced) observations: 70} \\
\hline Variable & Coefficient & Std. Error & t-Statistic & Prob. \\
\hline CEO_DUALITY & -0.053777 & 0.040781 & -1.318689 & 0.1922 \\
\hline BOARD_SIZE & -0.008374 & 0.007887 & -1.061803 & 0.2925 \\
\hline BOD_MEETINGS & 0.002351 & 0.003414 & 0.688651 & 0.4937 \\
\hline IND & -0.004481 & 0.064598 & -0.069375 & 0.9449 \\
\hline GENDER_DIVERSITY & 0.162940 & 0.195487 & 0.833507 & 0.4078 \\
\hline $\mathrm{C}$ & 0.119273 & 0.092478 & 1.289744 & 0.2020 \\
\hline R-squared & 0.067063 & \multicolumn{2}{|c|}{ Mean dependent var } & 0.069056 \\
\hline Adjusted R-squared & -0.055290 & \multicolumn{2}{|c|}{ S.D. dependent var } & 0.130737 \\
\hline S.E. of regression & 0.134303 & \multicolumn{2}{|c|}{ Akaike info criterion } & -1.057921 \\
\hline Sum squared resid & 1.100269 & \multicolumn{2}{|c|}{ Schwarz criterion } & -0.768829 \\
\hline Log likelihood & 46.02724 & \multicolumn{2}{|c|}{ Hannan-Quinn criter. } & -0.943090 \\
\hline F-statistic & 0.548112 & \multicolumn{2}{|c|}{ Durbin-Watson stat } & 2.982442 \\
\hline Prob (F-statistic) & \multicolumn{3}{|l|}{0.815524} & \\
\hline
\end{tabular}

ROA, as the corresponding P-values are more than 0.05 .

\subsubsection{The Relation between Board of Directors Characteristics and ROA}

By using regression analysis, it was found that there is an insignificant effect of CEO Duality on ROA, as the corresponding P-value is more than 0.05 . Therefore, there is a significant relationship between CEO Duality and ROA is not supported. Also, it was found that there is an insignificant effect of Board Size on ROA, as the corresponding P-value is more than 0.05 . Therefore, there is a significant relationship between Board Size and ROA is not supported. Also, it was found that there is an insignificant effect of Board meetings on ROA, as the corresponding $\mathrm{P}$-value is more than 0.05 . Therefore, there is a significant relationship between Board Meetings and ROA is not supported. Also, it was found that there is an insignificant effect of Independence of Board on ROA, as the corresponding $\mathrm{P}$-value is more than 0.05 . Therefore, there is a significant relationship between Board Independence and ROA is not supported.

Also, it was found that there is an insignificant effect of Gender diversity on ROA, as the corresponding P-value is more than 0.05. Therefore, there is a significant relationship between Gender Diversity and ROA is not supported.

Also, it was found that there is an insignificant effect of Ownership insider on $\mathrm{ROA}$, as the corresponding $\mathrm{P}$-value is more than 0.05 . Table 4 shows the regression 
Table 4. Regression model of independent variables on ROE.

\begin{tabular}{|c|c|c|c|c|}
\hline \multicolumn{5}{|c|}{ Dependent Variable: ROE } \\
\hline \multicolumn{5}{|c|}{ Method: Panel Least Squares } \\
\hline \multicolumn{5}{|c|}{ Sample (adjusted): 20142017} \\
\hline \multicolumn{5}{|c|}{ Periods included: 4} \\
\hline \multicolumn{5}{|c|}{ Cross-sections included: 21} \\
\hline \multicolumn{5}{|c|}{ Total panel (unbalanced) observations: 68} \\
\hline Variable & Coefficient & Std. Error & t-Statistic & Prob. \\
\hline CEO_DUALITY & -0.092251 & 0.047594 & -1.938280 & 0.0574 \\
\hline BOARD_SIZE & -0.004696 & 0.009112 & -0.515288 & 0.6083 \\
\hline BOD_MEETINGS & 0.002404 & 0.004110 & 0.584994 & 0.5608 \\
\hline IND & -0.089442 & 0.075796 & -1.180044 & 0.2427 \\
\hline GENDER_DIVERSITY & 0.131063 & 0.226178 & 0.579467 & 0.5645 \\
\hline R-squared & 0.189217 & \multicolumn{2}{|c|}{ Mean dependent var } & 0.144459 \\
\hline Adjusted R-squared & 0.079280 & \multicolumn{2}{|c|}{ S.D. dependent var } & 0.161306 \\
\hline S.E. of regression & 0.154780 & \multicolumn{2}{|c|}{ Akaike info criterion } & -0.770886 \\
\hline Sum squared resid & 1.413457 & \multicolumn{2}{|c|}{ Schwarz criterion } & -0.477128 \\
\hline Log likelihood & 35.21012 & \multicolumn{2}{|c|}{ Hannan-Quinn criter. } & -0.654490 \\
\hline F-statistic & 1.721145 & \multicolumn{2}{|c|}{ Durbin-Watson stat } & 0.951301 \\
\hline Prob(F-statistic) & 0.112355 & & & \\
\hline
\end{tabular}

model for the effect of Independent Variables; (CEO Duality, Board Size, Board meetings, Independence Board and Gender diversity) on ROE. It was found that there is an insignificant effect of CEO Duality, Board Size, Board meetings, Independence Board and Gender diversity on ROE, as the corresponding P-values are more than 0.05 with, coefficients of $-0.0922,-0.004,0.002,-0.089$ and 0.131 respectively.

\subsubsection{The Relation between Board of Directors Characteristics and ROE}

By using regression analysis, it was found that there is a significant negative effect of CEO Duality on ROE, as the corresponding P-value is less than 0.05 . Therefore, the first sub hypothesis of the second hypothesis that there is a significant relationship between CEO Duality and ROE is supported. Also, it was found that there is an insignificant effect of Board size on ROE, as the corresponding P-value is more than 0.05 . Therefore, there is a significant relationship between Board Size and ROE is not supported. Also, it was found that there is an insignificant effect of Board meetings on ROE, as the corresponding P-value is more than 0.05 .

Therefore, there is a significant relationship between Board Meetings and ROE is not supported. Also, it was found that there is an insignificant effect of Independence Board on ROE, as the corresponding P-value is more than 0.05. Therefore, there is a significant relationship between Board Independence and ROE is not supported.

Also, it was found that there is an insignificant effect of Gender diversity on 
ROE, as the corresponding P-value is more than 0.05 . Therefore, there is a significant relationship between Gender Diversity and ROE is not supported.

Table 5 shows the regression model for the effect of Independent Variables; (CEO Duality, Board Size, Board meetings, Independence Board and Gender diversity) on Q Ratio. It was found that there is an insignificant effect of CEO Duality, Board Size, Independence Board and Gender diversity, on Q Ratio, as the corresponding P-values are more than 0.05 . On the other hand, there is a significant positive effect of Board meetings, as p-value less than 0.05 and coefficient of 0.612 . Also, the $\mathrm{R}$ square is 0.742 , which means that the model explains $74.2 \%$ of the variation in Q Ratio.

\subsubsection{The Relation between Board of Directors Characteristics and Q Ratio}

By using regression analysis, it was found that there is a significant negative effect of CEO Duality on Q Ratio, as the corresponding P-value is more than 0.05. Therefore, there is a significant relationship between CEO Duality and Q Ratio is supported. Also, it was found that there is a significant negative effect of Board size on Q Ratio, as the corresponding P-value is less than 0.05 . Therefore, there is a significant relationship between Board Size and Q Ratio is supported. Also, it was found that there is a significant positive effect of Board meetings on Q Ratio, as the corresponding P-value is less than 0.05 . Therefore, there is a significant

Table 5. Regression model of independent variables on $\mathrm{Q}$ ratio.

\begin{tabular}{|c|c|c|c|c|}
\hline \multicolumn{5}{|c|}{ Dependent Variable: Q_RATIO } \\
\hline \multicolumn{5}{|c|}{ Method: Panel Least Squares } \\
\hline \multicolumn{5}{|c|}{ Sample (adjusted): 20142017} \\
\hline \multicolumn{5}{|c|}{ Periods included: 4} \\
\hline \multicolumn{5}{|c|}{ Cross-sections included: 9} \\
\hline \multicolumn{5}{|c|}{ Total panel (unbalanced) observations: 21} \\
\hline Variable & Coefficient & Std. Error & t-Statistic & Prob. \\
\hline CEO_DUALITY & -3.054493 & 1.898977 & -1.608494 & 0.1337 \\
\hline BOARD_SIZE & -0.886427 & 0.646950 & -1.370163 & 0.1957 \\
\hline BOD_MEETINGS & 0.612056 & 0.196569 & 3.113700 & 0.0090 \\
\hline IND & 3.694221 & 5.872432 & 0.629078 & 0.5411 \\
\hline GENDER_DIVERSITY & -5.441188 & 12.43723 & -0.437492 & 0.6695 \\
\hline R-squared & 0.742556 & \multicolumn{2}{|c|}{ Mean dependent var } & 2.045238 \\
\hline Adjusted R-squared & 0.570927 & \multicolumn{2}{|c|}{ S.D. dependent var } & 4.528180 \\
\hline S.E. of regression & 2.966123 & \multicolumn{2}{|c|}{ Akaike info criterion } & 5.309915 \\
\hline Sum squared resid & 105.5746 & \multicolumn{2}{|c|}{ Schwarz criterion } & 5.757568 \\
\hline Log likelihood & -46.75411 & \multicolumn{2}{|c|}{ Hannan-Quinn criter. } & 5.407067 \\
\hline F-statistic & 4.326520 & \multicolumn{2}{|c|}{ Durbin-Watson stat } & 1.911740 \\
\hline Prob (F-statistic) & 0.011635 & & & \\
\hline
\end{tabular}


relationship between Board Meetings and Q Ratio is supported.

Also, it was found that there is an insignificant effect of Independence Board on Q Ratio, as the corresponding P-value is more than 0.05. Therefore, there is a significant relationship between Board Independence and Q Ratio is not supported. Also, it was found that there is an insignificant effect of Gender diversity on Q Ratio, as the corresponding P-value is more than 0.05. Therefore, there is a significant relationship between Gender Diversity and Q Ratio is not supported.

\subsection{Descriptive Statistics}

This study examined the effect of Board of Directors Characteristics on firm financial performance on practices of listed companies in Egypt, from 2012 to 2017. The empirical results of the event study were presented (Table 6).

Firstly, the relationship between CEO Duality and firm's financial performance under ROA, ROE and Tobin's $Q$ performance measures. It was found the result was found there is a significant relationship between CEO and firm's financial performance. This finding reflects the need to strengthen the compliance to the Corporate Governance Code in Egypt that relates to the duality status of the board of directors. Although the Code clearly restricts managers from holding these two posts, duality persists in practice, and the CEO-Chairman are managing earnings more than firms with the two roles separated. This study concludes that compliance to the Code by separating the roles of chairman and $\mathrm{CEO}$ in this regard has shown its positive impact.

Secondly, the relationship between Board Size and firm's financial performance under ROA, ROE and Tobin's Q performance measures. The result was found it was found there is a significant relationship between Board Size and firm's financial performance. The results indicate that larger boards are more effective in monitoring financial reporting.

Thirdly, the empirical results report that the relationship between Board Meetings and firm's Financial performance under ROA, ROE and Tobin's $Q$ performance measures. It was found there is a significant relationship between Board meetings and firm's financial performance. This means the Board meeting has no effect on company performance.

Fourthly, the empirical results indicate that there was insignificant relationship between Independence board members and firm's financial performance under ROA, ROE and Tobin's $Q$ performance measures the result was found it was found there is no significant relationship between Independence board members and firm's financial performance. This implies that external directors have not got influence on firms' financial performance in the Egyptian market. The results may be interpreted due to the dominance of family-controlled firms in Egypt, which may result in family dominance over board matters as a result of weak corporate governance regimes.

Fifth, the relationship between Gender Diversity and firm's financial performance under ROA, ROE and Tobin's $Q$ performance measures it was found was found no significant relationship between Gender Diversity and firm's financial 
Table 6. Regression model of independent variables on $\mathrm{Q}$ ratio.

\begin{tabular}{|c|c|c|c|}
\hline Serial & Description & Results & Final results \\
\hline $\mathrm{H}_{11}$ & $\begin{array}{c}\text { There is a significant relationship between CEO } \\
\text { Duality and ROA }\end{array}$ & $\begin{array}{c}\text { Not Supported } \\
\text { Coefficient }=-0.010780 \\
\text { p-value }=0.6514\end{array}$ & \\
\hline $\mathrm{H}_{12}$ & $\begin{array}{c}\text { There is a significant relationship between CEO } \\
\text { Duality and ROE }\end{array}$ & $\begin{array}{c}\text { Supported } \\
\text { Coefficient }=-0.160810 \\
\text { p-value }=0.0128\end{array}$ & partially supported \\
\hline $\mathrm{H}_{13}$ & $\begin{array}{c}\text { There is a significant relationship between CEO } \\
\text { Duality and Q Ratio }\end{array}$ & $\begin{array}{c}\text { Supported } \\
\text { Coefficient }=-1.925918 \\
\text { p-value }=0.0182\end{array}$ & \\
\hline $\mathrm{H}_{21}$ & $\begin{array}{l}\text { There is a significant relationship between Board } \\
\text { Size and ROA }\end{array}$ & $\begin{array}{c}\text { Not Supported } \\
\text { Coefficient }=-0.000651 \\
\text { p-value }=0.8709\end{array}$ & \\
\hline $\mathrm{H}_{22}$ & $\begin{array}{l}\text { There is a significant relationship between Board } \\
\text { size and ROE }\end{array}$ & $\begin{array}{c}\text { Not Supported } \\
\text { Coefficient }=-0.001010 \\
\text { p-value }=0.9275\end{array}$ & partially supported \\
\hline $\mathrm{H}_{23}$ & $\begin{array}{c}\text { There is a significant relationship between Board } \\
\text { size and Q Ratio }\end{array}$ & $\begin{array}{c}\text { Supported } \\
\text { Coefficient }=-0.409031 \\
\text { p-value }=0.0024\end{array}$ & \\
\hline $\mathrm{H}_{31}$ & $\begin{array}{l}\text { There is a significant relationship between Board } \\
\text { meetings and ROA }\end{array}$ & $\begin{array}{c}\text { Not Supported } \\
\text { Coefficient }=-0.000245 \\
\text { p-value }=0.8908\end{array}$ & \\
\hline $\mathrm{H}_{32}$ & $\begin{array}{l}\text { There is a significant relationship between Board } \\
\text { meetings and ROE }\end{array}$ & $\begin{array}{c}\text { Not Supported } \\
\text { Coefficient }=-0.001441 \\
\text { p-value }=0.7680\end{array}$ & partially supported \\
\hline $\mathrm{H}_{33}$ & $\begin{array}{c}\text { There is a significant relationship between Board } \\
\text { meetings and Q Ratio }\end{array}$ & $\begin{array}{c}\text { Supported } \\
\text { Coefficient }=0.126278 \\
\text { p-value }=0.0419\end{array}$ & \\
\hline $\mathrm{H}_{41}$ & $\begin{array}{l}\text { There is a significant relationship between } \\
\text { Independence Board and ROA }\end{array}$ & $\begin{array}{c}\text { Not Supported } \\
\text { Coefficient }=-0.054702 \\
\text { p-value }=0.1740\end{array}$ & \\
\hline $\mathrm{H}_{42}$ & $\begin{array}{l}\text { There is a significant relationship between } \\
\text { Independence Board on ROE }\end{array}$ & $\begin{array}{c}\text { Not Supported } \\
\text { Coefficient }=-0.008531 \\
\text { p-value }=0.9380\end{array}$ & $\begin{array}{l}\text { Not supported } \\
\text { H4 is rejected }\end{array}$ \\
\hline $\mathrm{H}_{43}$ & $\begin{array}{l}\text { There is a significant relationship between } \\
\text { Independence Board and Q Ratio }\end{array}$ & $\begin{array}{c}\text { Not Supported } \\
\text { Coefficient }=0.060982 \\
\text { p-value }=0.9674\end{array}$ & \\
\hline $\mathrm{H}_{51}$ & $\begin{array}{c}\text { There is a significant relationship between } \\
\text { Gender diversity and ROA }\end{array}$ & $\begin{array}{c}\text { Not Supported } \\
\text { Coefficient }=-0.002659 \\
\text { p-value }=0.9808\end{array}$ & \\
\hline $\mathrm{H}_{52}$ & $\begin{array}{l}\text { There is a significant relationship between } \\
\text { Gender diversity and ROE }\end{array}$ & $\begin{array}{c}\text { Not Supported } \\
\text { Coefficient }=0.290599 \\
\text { p-value }=0.3448\end{array}$ & $\begin{array}{l}\text { Not supported } \\
\text { H5 is rejected }\end{array}$ \\
\hline $\mathrm{H}_{53}$ & $\begin{array}{l}\text { There is a significant relationship between } \\
\text { Gender diversity and Q Ratio }\end{array}$ & $\begin{array}{c}\text { Not Supported } \\
\text { Coefficient }=-1.247979 \\
\text { p-value }=0.7633\end{array}$ & \\
\hline
\end{tabular}


performance. And this means that the presence of women in the board does not effect on the company's results, the negative impact on firm value may be due to social norms and how they are restricted for women, having its effect on the investors' perception. In certain societies, investors may believe that women lack the competency needed for the job. Also, the findings of the current study lend empirical support to [56] who believe that gender diversity may affect performance negatively due to woman being risk averse and due to the costs associated with high turnover and absenteeism rates.

At the same time, some the Board of Directors Structure variables have an insignificant impact on Egyptian firms performance. This result may be interpreted by the absence of a real application for the appropriate principles and standards of corporate governance to the listed firms in the Egypt.

\section{Summary, Conclusion and Recommendations}

This study examined the effect of Board of Directors Characteristics on firm financial performance on practices of listed companies in Egypt, from 2012 to 2017. The empirical results of the event study were presented.

\subsection{Recommendations and Implications of the Study}

This study suggests some recommendations, Strengthen the compliance to the Corporate Governance Code in Egypt that relates to the duality status of the board of directors chairman. Although the Code clearly restricts managers from holding these two posts, duality persists in practice, and the CEO-Chairman are deteriorating performance more than firms with the two roles separated. The results mentioned above signify the importance of corporate governance mechanisms in enhancing the quality of financial reporting process. Thus, these results should be considered by regulators in Egypt in order to begin the necessary actions for legally the Egyptian.

Attention should be drawn to the fact that the remuneration of executive directors is normally determined on the basis of an annual share of profits amounting to 10 percent of net income, after deducting the legal reserves and. As such, the level of compensation relies mainly on the figure of reported earnings and, therefore, this may create considerable pressure on managers to maximize earnings in order to increase their remuneration [55].

\subsection{Limitations of the Research}

This study is that it focuses solely on board characteristics as a dimension of the corporate governance. Also this study is using a small sample of 37 companies although, this sample is observed for six years, it is only representative for Egyptian-listed companies. This sample may be small in size and, by construction, composed of the most active Egyptian listed companies and thus may not be representative of the population of Egyptian firms, consequently, caution should be considered in evaluating the results. Also, this study focuses on the five major 
variables that were used by prior researchers. Also our results may not apply to other countries since each emerging economy is different in a different way and we have chosen an emerging economy, Egypt as our context.

\subsection{Suggestions for Further Future Studies}

The period of study for this research is only six years (2012-2017), however, further research can consider more time frames based on the availability of the annual reports and even can make a comparison between the era before the Egyptian revolution and the era after it [50].

Another avenue for further research is to include more factors that affect the relationship between Board of Directors Characteristics and financial performance of firms such as board of directors gender, the level of education of board members, years of experience of board members and also other attributes other than board characteristics to reach a significant relationship between dependent and independent variables. Finally, other relevant areas regarding corporate governance and its effect on firm performance can be added like ownership and audit committee.

\section{Conflicts of Interest}

The authors declare no conflicts of interest regarding the publication of this paper.

\section{References}

[1] Bansal, N. and Sharma, A.K. (2016) Audit Committee, Corporate Governance and Firm Performance: Empirical Evidence from India. International Journal of Economics and Finance, 8, 103. https://doi.org/10.5539/ijef.v8n3p103

[2] Amer, M. (2016) Measuring the Effect of the Board of Directors and Audit Committee Characteristics on Firm Financial Performance in Egypt. Doctoral Dissertation, Cardiff Metropolitan University.

[3] Demirag, I., Ed. (2005) Corporate Social Responsibility, Accountability and Governance: Global Perspectives. Greenleaf Publications.

[4] La Porta, R., Lopez-de-Silanes, F., Shleifer, A. and Vishny, R.W. (1997) Legal Determinants of External Finance. The Journal of Finance, 52, 1131-1150. https://doi.org/10.1111/j.1540-6261.1997.tb02727.x

[5] ICCWBO (2006) www.iccwbo.org/CorpGov/whycorpgov.asp

[6] Nahar Abdullah, S. (2004) Board Composition, CEO Duality and Performance among Malaysian Listed Companies. Corporate Governance: The International Journal of Business in Society, 4, 47-61. https://doi.org/10.1108/14720700410558871

[7] He, J. and Huang, Z. (2011) Board Informal Hierarchy and Firm Financial Performance: Exploring a Tacit Structure Guiding Boardroom Interactions. Academy of Management Journal, 54, 1119-1139. https://doi.org/10.5465/amj.2009.0824

[8] O'Connell, V. and Cramer, N. (2010) The Relationship between Firm Performance and Board Characteristics in Ireland. European Management Journal, 28, 387-399. https://doi.org/10.1016/j.emj.2009.11.002

[9] Campbell, K. and Mínguez-Vera, A. (2008) Gender Diversity in the Boardroom and 
Firm Financial Performance. Journal of Business Ethics, 83, 435-451. https://doi.org/10.1007/s10551-007-9630-y

[10] Abidin, Z.Z., Kamal, N.M. and Jusoff, K. (2009) Board Structure and Corporate Performance in Malaysia. International Journal of Economics and Finance, 1, 150. https://doi.org/10.5539/ijef.v1n1p150

[11] Mallette, P. and Fowler, K.L. (1992) Effects of Board Composition and Stock Ownership on the Adoption of "Poison Pills". Academy of Management Journal, 35, 1010-1035.

[12] Goyal, V.K. and Park, C.W. (2002) Board Leadership Structure and CEO Turnover. Journal of Corporate Finance, 8, 49-66. https://doi.org/10.1016/S0929-1199(01)00028-1

[13] Fama, E.F. and Jensen, M.C. (1983) Separation of Ownership and Control. The Journal of Law and Economics, 26, 301-325. https://doi.org/10.1086/467037

[14] Fosberg, R.H. (1999) Leadership Structure and CEO Compensation. American Business Review, 17, 50.

[15] Mahrous, S.A. (2014) The Effect of Board Characteristics on the Financial Performance of Firms: An Empirical Study on the Most Active Firms in the Egyptian Stock Exchange. Doctoral Dissertation, Master's Thesis.

[16] Weir, C., Laing, D. and McKnight, P.J. (2002) Internal and External Governance Mechanisms: Their Impact on the Performance of Large UK Public Companies. Journal of Business Finance \& Accounting, 29, 579-611. https://doi.org/10.1111/1468-5957.00444

[17] Soliman, M. and Ragab, A.A. (2013) Board of Director's Attributes and Earning Management: Evidence from Egypt. International Business and Social Sciences Research Conference, Dubai, January 2013.

[18] Persons, O.S. (2006) Corporate Governance and Non-Financial Reporting Fraud. The Journal of Business and Economic Studies, 12, 27-40.

[19] Anderson, R.C., Mansi, S.A. and Reeb, D.M. (2004) Board Characteristics, Accounting Report Integrity, and the Cost of Debt. Journal of Accounting and Economics, 37, 315-342. https://doi.org/10.1016/j.jacceco.2004.01.004

[20] Coles, J.L., Daniel, N.D. and Naveen, L. (2008) Boards: Does One Size Fit All? Journal of Financial Economics, 87, 329-356. https://doi.org/10.1016/j.jfineco.2006.08.008

[21] Dalton, D.R., Daily, C.M., Ellstrand, A.E. and Johnson, J.L. (1998) Meta-Analytic Reviews of Board Composition, Leadership Structure, and Financial Performance. Strategic Management Journal, 19, 269-290. https://doi.org/10.1002/(SICI)1097-0266(199803)19:3<269::AID-SMJ950>3.0.CO;2-K

[22] Xie, B., Davidson III, W.N. and DaDalt, P.J. (2003) Earnings Management and Corporate Governance: The Role of the Board and the Audit Committee. Journal of Corporate Finance, 9, 295-316. https://doi.org/10.1016/S0929-1199(02)00006-8

[23] Kiel, G.C. and Nicholson, G.J. (2003) Board Composition and Corporate Performance: How the Australian Experience Informs Contrasting Theories of Corporate Governance. Corporate Governance: An International Review, 11, 189-205. https://doi.org/10.1111/1467-8683.00318

[24] Coleman Kyereboah, A. and Biekpe, N. (2007) On the Determinants of Board Size and Its Composition: Additional Evidence from Ghana. Journal of Accounting \& Organizational Change, 3, 68-77. https://doi.org/10.1108/18325910710732867

[25] Yermack, D. (1996) Higher Market Valuation of Companies with a Small Board of 
Directors. Journal of Financial Economics, 40, 185-211. https://doi.org/10.1016/0304-405X(95)00844-5

[26] Bhatt, R.R. and Bhattacharya, S. (2015) Do Board Characteristics Impact Firm Performance? An Agency and Resource Dependency Theory Perspective. Asia-Pacific Journal of Management Research and Innovation, 11, 274-287. https://doi.org/10.1177/2319510X15602973

[27] Lipton, M. and Lorsch, J.W. (1992) A Modest Proposal for Improved Corporate Governance. The Business Lawyer, 48, 59-77.

[28] Jensen, M.C. (1993) The Modern Industrial Revolution, Exit, and the Failure of Internal Control Systems. The Journal of Finance, 48, 831-880. https://doi.org/10.1111/j.1540-6261.1993.tb04022.x

[29] Ntim, C.G. (2009) Internal Corporate Governance Structures and Firm Financial Performance: Evidence from South African Listed Firms. Doctoral Dissertation, University of Glasgow, Glasgow.

[30] Byrne, J. (1996) The National Association of Corporate Directors' New Guidelines Won't Tolerate Inattentive, Passive Uninformed Board Members. Business Week, 25.

[31] Mangena, M. and Tauringana, V. (2008) A Study of the Relationship between Audit Committee Factors and Voluntary External Auditor Involvement in UK Interim Reporting. International Journal of Auditing, 12, 43-63. https://doi.org/10.1111/j.1099-1123.2008.00369.x

[32] Pfeffer, J. (1972) Size and Composition of Corporate Boards of Directors: The Organization and Its Environment. Administrative Science Quarterly, 17, 218-228. https://doi.org/10.2307/2393956

[33] Hillman, A.J. and Dalziel, T. (2003) Boards of Directors and Firm Performance: Integrating Agency and Resource Dependence Perspectives. Academy of Management Review, 28, 383-396. https://doi.org/10.5465/amr.2003.10196729

[34] Zahra, S.A. and Pearce, J.A. (1989) Boards of Directors and Corporate Financial Performance: A Review and Integrative Model. Journal of Management, 15, 291-334. https://doi.org/10.1177/014920638901500208

[35] Johnson, J.L., Daily, C.M. and Ellstrand, A.E. (1996) Boards of Directors: A Review and Research Agenda. Journal of Management, 22, 409-438. https://doi.org/10.1177/014920639602200303

[36] Peasnell, K.V., Pope, P.F. and Young, S. (2005) Board Monitoring and Earnings Management: Do Outside Director's Influence Abnormal Accruals? Journal of Business Finance \& Accounting, 32, 1311-1346. https://doi.org/10.1111/j.0306-686X.2005.00630.x

[37] Carter, D.A., Simkins, B.J. and Simpson, W.G. (2003) Corporate Governance, Board Diversity, and Firm Value. Financial Review, 38, 33-53. https://doi.org/10.1111/1540-6288.00034

[38] Reguera-Alvarado, N., de Fuentes, P. and Laffarga, J. (2015) Does Board Gender Diversity Influence Financial Performance? Evidence from Spain. Journal of Business Ethics, 141, 337-350.

[39] Erhardt, N.L., Werbel, J.D. and Shrader, C.B. (2003) Board of Director Diversity and Firm Financial Performance. Corporate Governance: An International Review, 11, 102-111. https://doi.org/10.1111/1467-8683.00011

[40] Ahern, K.R. and Dittmar, A.K. (2012) The Changing of the Boards: The Impact on Firm Valuation of Mandated Female Board Representation. The Quarterly Journal 
of Economics, 127, 137-197. https://doi.org/10.1093/qje/qjr049

[41] Joecks, J., Pull, K. and Vetter, K. (2013) Gender Diversity in the Boardroom and Firm Performance: What Exactly Constitutes a "Critical Mass"? Journal of Business Ethics, 118, 61-72. https://doi.org/10.1007/s10551-012-1553-6

[42] Solakoglu, M.N. (2013) The Role of Gender Diversity on Firm Performance: A Regression Quantile Approach. Applied Economics Letters, 20, 1562-1566. https://doi.org/10.1080/13504851.2013.829184

[43] Solakoglu, M.N. and Demir, N. (2016) The Role of Firm Characteristics on the Relationship between Gender Diversity and Firm Performance. Management Decision, 54, 1407-1419. https://doi.org/10.1108/MD-02-2015-0075

[44] Zeitun, R. and Tian, G.G. (2007) Does Ownership Affect a Firm's Performance and Default Risk in Jordan? Corporate Governance, 7, 66-82. https://doi.org/10.1108/14720700710727122

[45] Shukeri, S.N., Shin, O.W. and Shaari, M.S. (2012) Does Board of Director's Characteristics Affect Firm Performance? Evidence from Malaysian Public Listed Companies. International Business Research, 5, 120-127.

https://doi.org/10.5539/ibr.v5n9p120

[46] Bathula, H. (2008) Board Characteristics and Firm Performance: Evidence from New Zealand. Doctoral Dissertation, Auckland University of Technology, Auckland.

[47] Carcello, J.V., Hermanson, D.R., Neal, T.L. and Riley Jr., R.A. (2002) Board Characteristics and Audit Fees. Contemporary Accounting Research, 19, 365-384. https://doi.org/10.1506/CHWK-GMQ0-MLKE-K03V

[48] Van Diepen, N. (2015) The Effect of Gender, Age and Nationality Diversity on Company Performance-Evidence from the Netherlands.

[49] Pathirawasam, C. (2013) Internal Factors which Determine Financial Performance of Firms: With Special Reference to Ownership Concentration. Innovation and Knowledge Management: A Global Competitive Advantage, 1-4, 967-977.

[50] Youssef, A. and Bayoumi, M. (2015) Investigating the Relationship between Corporate Governance and Banks' Financial Performance: Egypt Case. Corporate Ownership \& Control, 13, 1177-1190.

[51] Taghizadeh, M. and Saremi, Y. (2013) Board of Directors and Firms Performance: Evidence from Malaysian Public Listed Firms. IDRC Conference, Dubai, 178-182.

[52] Zhang, H. and Kyaw, K. (2017) Ownership Structure and Firm Performance: An Empirical Analysis of Chinese Companies. Applied Economics and Finance, 4, 57-64. https://doi.org/10.11114/aef.v4i2.2109

[53] Gugong, B.K., Arugu, L.O. and Dandago, K.I. (2014) The Impact of Ownership Structure on the Financial Performance of Listed Insurance Firms in Nigeria. International Journal of Accounting, Finance and Management Science, 4, 409-416. https://doi.org/10.6007/IJARAFMS/v4-i1/698

[54] Boone, A., Field, L., Karpoff, J.M. and Raheja, C.G. (2007) The Determinants of Corporate Board Size and Composition: An Empirical Analysis. Journal of Financial Economics, 85, 66-101. https://doi.org/10.1016/j.jfineco.2006.05.004

[55] Soliman, M. (2013) Corporate Governance and Earning Management: Evidences from Emerging Markets. LAP Lambert Academic Publishing.

[56] Coleman, A., Adjasi, C. and Abor, J. (2007) Corporate Governance and Firm Performance: Evidence from Ghanaian Listed Companies. Corporate Ownership and Control, 4, 123-132. 
[57] Dalton, D.R. and Dalton, C.M. (2010) Women and Corporate Boards of Directors: The Promise of Increased, and Substantive, Participation in the Post-Sarbanes-Oxley Era. Business Horizons, 53, 257-268. https://doi.org/10.1016/j.bushor.2009.12.004

[58] Galal, H.M. and Soliman, M.M. (2017) The Effect of Ownership Structure on Firm's Financial Performance: An Empirical Study on the Most Active Firms in the Egyptian Stock Exchange. European Journal of Business and Management, 9. 